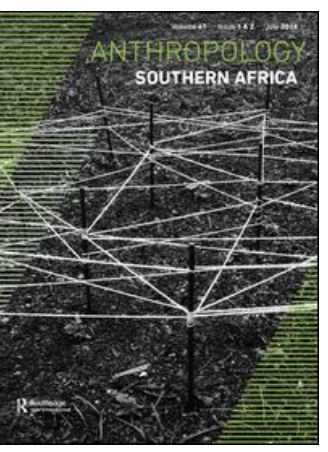

\title{
Anthropology Southern Africa
}

\section{Rethinking medicinal plants and plant medicines}

\section{Diana Gibson}

To cite this article: Diana Gibson (2018) Rethinking medicinal plants and plant medicines, Anthropology Southern Africa, 41:1, 1-14, DOI: 10.1080/23323256.2017.1415154

To link to this article: https://doi.org/10.1080/23323256.2017.1415154

\section{曲 Published online: 08 Mar 2018.}

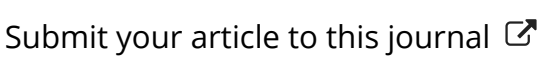

\section{Article views: 248}

Q View related articles $\square$

View Crossmark data \lceil

Citing articles: 1 View citing articles 4 


\title{
Rethinking medicinal plants and plant medicines
}

\author{
Diana Gibson \\ Department of Anthropology and Sociology, University of the Western Cape, Bellville, South Africa \\ Email:dgibson@uwc.ac.za
}

\begin{abstract}
Because plants are perceived as sessile and immobile, they are often represented as objects or things in current literature. In this paper, I explore variations and shifts in research and literature since 2000 that reconsider the ways that plant-related ideas, expertise and practices intersect in multiple associations related to medicinal plants. I argue that, in their relationship with humans, plants have histories, are mobile and can also bring about political and other effects. I use ethnographic material from Namibia and the Western Cape of South Africa to review medicinal plants, by focusing on human-plant relations and the incorporation of plants as non-human subjects with non-intentional agency.
\end{abstract}

Keywords: agency; interdisciplinary; knowledge; medicinal; non-human; plants

\section{Introduction: rethinking medicinal plants}

Medicinal plants have long been connected to and given value in various sociocultural settings across the world (Ryan 2012). An example is Sceletium tortuosum (locally known as kanna or kougoed), a South African plant with a history as "traditional" medicine, chewed for centuries for medicinal, soothing purposes, to produce a sense of elation and to increase sensitivity to tactile stimuli. The plant was utilised by San and Khoikhoi during healing rituals (Cleversley 2002; Smith et al. 1996) and a tincture was subsequently adopted by colonial farmers for sedation and as an analgesic (Terburg et al. 2013, 2708; Cohen 2015).

Recently, standardised $S$. tortuosum extracts were tested in clinical trials involving healthy adults. Its effect, based on synergistic interactions between active constituents, highlights the complex entanglement of humans, research and representations of medicinal plants with histories of "traditional" use for remedial and prophylactic purposes. The S. tortuosum extract proved safe to reduce anxiety (Terburg et al. 2013) and was approved under the name of Elev8 as complementary medicine by South Africa's Medicines Control Council (MCC). It is now sold as Zembrin in America. Phyto-extracts and dried $S$. tortuosum are available in shops or online. ${ }^{2}$ As a result, $S$. tortuosum has migrated and is increasingly being cultivated as a crop, also in countries far from its origins. ${ }^{3}$

Historically, medicinal plants were arguably extracted in terms of specific human-plant relations, ontologies and webs of meaning that contextualised their related knowledges within a specific setting, as well as making use of understandings of the plants' therapeutic properties in traditional healing. Currently, medicinal plants are increasingly being integrated into economic enterprises and scientific investigations (Petrovska 2012), as is reflected in the above examples, such that knowledge/s about plants, as well as plants themselves, are made increasingly mobile. Furthermore, present-day analyses of plants show that they have their own potentialities that entail more than is envisaged in human-centric understandings and use. For instance, studies show that some animals, reptiles and insects also ingest medicinal plants as prophylactics or in response to parasitic infections (de Roode, Lefèvre, and Hunter 2013).

The transformative therapeutic abilities of medicinal plants have influenced societal, cultural and medicinal practices, as well as environments and ecosystems. Medicinal plants, used in a variety 
of ecological settings, probably developed or perhaps "co-evolved" as part of biocultural diversity (Maffi 2007, 269). Plants are alive, photosynthesise and produce chemicals to protect themselves, a process that equally benefits humans, making the plants a valuable field of study (Bussmann 2013).

Interest in, and attention to, plants developed as European exploration and colonisation extended into Africa, Asia and the Americas. Travellers, naturalists, botanists, anthropologists and others became attentive to local people and to the many new medicinal, food, aesthetic and "useful" plants encountered amongst them: they collected and transported numerous specimens and recorded their uses, local names, local symbolisms and meanings. With the global movement of medicinal plants, scholars studied dynamics and shifts in "traditional" knowledge concerning them (Low 2007; Pieroni and Vandebroek 2007). In literature, plant use is accordingly often deliberated in relation to human-plant interactions, knowledge, practices, beliefs and meaning (Ogden, Hall, and Tanita 2013).

In this paper, I review literature published since 2000 that may help us to ponder on and with medicinal plants, particularly in relation to fieldwork I have conducted in Namibia and in the Matzikama region of the Western Cape. The overall purpose of the paper is to explore new ways to think through medicinal plants and along with them. It is evident that much of the literature represents medicinal plants as passive objects, yet it also indicates plant histories, mobility, economic and political effects. To examine medicinal plants differently, I draw on works on Amerindian ontologies to argue that we could potentially contemplate medicinal plants as "beings." I scrutinise literature that elevates a rethinking of medicinal plants as actants. Finally, I examine interdisciplinary investigations on medicinal plants, to reflect on them as agents/actants/beings.

\section{Historical medicinal plant encounters and mobility}

Because plants are sessile, they are often perceived or represented as passive. Yet their extensive histories show remarkable mobility, activity and adaptability. As part of the global flow of knowledge and circulation of commodities, plants have been described, discussed, traded, stolen or translocated into new geographical areas; and they have been disseminated into various systems of healing and medicinal compendiums (Osseo-Asare 2014; Gänger 2015, 47). Exchanges and movements of medicinal plants occur locally and globally and involve transactions and translations of traditional knowledge and expertise at cultural, intellectual, political and economic levels (Hayden 2002). Like humans, plants migrate from rural to urban settings, between countries and continents (see Pieroni and Vandebroek 2007; van Andel and Westers 2013). Plants are integral to the local and global processes that reproduce, change and influence our societies and landscapes (Schiebinger 2004). When plants relocate or are transferred to new contexts, their use and the knowledge systems within which they existed can shift (van Andel and Westers 2010), they adapt to places and they can transform it.

Besides $S$. tortuosom, the use of the poison arrow vine (Strophanthus species) is a good example. Hokkanen (2012) elaborates on the multifaceted connections between colonialism, commercial interests and the production of medical and scientific knowledge in relation to Strophantus kombe between 1859 and 1915 in Malawi $(2012,589)$. Strophantus was used as arrow poison and initially feared by British colonisers; a botanist sent samples to Kew Gardens, then the centre of the British imperial botanical enterprise. S. kombe seeds and plants were subsequently linked through a network, which ranged from local people and particular geographical sites in Malawi to medical research facilities in Edinburgh and London, to the Burroughs Wellcome Company that began to produce strophantin tinctures to treat heart ailments among European patients.

Similarly Cannabis sativa (dagga) originated in Asia and was introduced to Southern Africa centuries ago. It has spread around the world, affecting humans and generating economic, political and cultural effects (Pollan 2002). As a medicinal plant with psychoactive properties, it has meaning in certain religions and ritual practices. In Matzikama, Rastafari bush doctors burn and smoke dagga as a sacrament to enhance their "spiritual connection with Jah and the environment" 
and to heighten a sense of wholeness within themselves and unity with other members of the community (Philander 2010, 203). Here dagga has created new relationships through its psychoactive effects.

Pollan (2002) argues that Cannabis plants ensured their own survival by producing chemicals that protected them from pests and predators, but also altered human perception and experience. Cannabis excels at biochemistry: it photosynthesises and creates active compounds that affect humans. Because of this transformative ability Cannabis plants are valued, sought, traded, utilised and regulated (Pollan 2002). Peoples' appetite for this plant enhanced its survival through human cultivation. It also led to legislation on marijuana and to global collaboration on drug enforcement. The literature discussed so far broadly analyses medicinal plants as "objects" performing various functions related to healing. Yet these plants also travel and bring about economic, political and physical effects: they can create new relationships.

\section{Conceptualisations of medicinal plants}

Over the past years, colleagues, students, local participants and I have conducted interdisciplinary research on medicinal plants in the Western Cape and, in my case, also Namibia, as part of an investigation into human-plant knowledges and relationships. A pertinent question that emerged through this work was whether we could think about medicinal plant knowledge, affect and plants' ability to produce change differently from how they had been thought about in the past? Could we, in fact, make sense of plants as actants, entities that can have an effect on their environments and relationships within it?

In our research, we engaged more intimately with plants than we had done in any research study before. Working closely with elderly people who often use plant medicines, plant practitioners and healers living in our research areas, we searched for medicinal plants in the veld and mountains of the Western Cape, learning to recognise them amidst other vegetation and in different seasons, becoming attentive to when they flowered, bore seed or fruit: touching, handling, smelling, tasting them, drinking plant decoctions and infusions, and making soap and oils. We planted seeds and made cuttings, commented on plants' growth, flowers, leaves and seeds. We watched plants in the veld, noting their exact latitude and longitude and describing them and the soil they grew in. We measured them, dug them out and prepared them for pressing and botanical identification. We thus mobilised plants as sample specimens and recombined them with taxonomical classificatory "tools" and herbarium specimens. In this way, they became botanical entities and available to others for future study and reference.

These steps enabled us to link the plants to texts, illustrations and photographs that helped us to identify them and which often also described their history, habitat, frequency, distribution and habit. ${ }^{4}$ We also scrutinised literature related to medicinal plants specifically and to plants in general in a variety of disciplines. During the research process, the vitality of the plants struck us. For example, during a period when we were absent from campus, a neatly pressed, dessicated Hoodia gordonii (ghaap), prepared and mounted for the herbarium, had pushed out small flowers: despite rigorous efforts to kill it, it exhibited its lively materiality. On another occasion, I watched and timed a Carpobrotus edulis (suurvy) opening its blossom, then rushed it to a plant press in my office. I was manipulating and transporting the plant, which through its own liveliness was, in turn, captivating myself and others. Students turned around to admire it, remarked on the big purple flower or enquired why I was carrying it. Some told of their own experience with, and family memories of, using it. The plant itself had engaged them, just as it had earlier attracted bees, beetles and a tortoise in the veld. Throughout the research process, our experiences with plants obliged us to try to find new ways to think with and through them, to engage with them differently, acknowledging their ability to transform. We scrutinised the literature and consulted the local people we had been working with for different insights into medicinal plants.

In 2008 in Namibia, /Kunta Kashe, ${ }^{5}$ an aged $n / u m k x a o$ [the owner of $n / u m$ healing power], told 
me that his uncle Dam Toma, also a n/umkxao, had sometimes used Boophone disticha (malgif) to induce a trance and to heal. I was taken aback - B. disticha is poisonous. I later read that in South Africa $B$. disticha is used to manage inflammatory conditions; lesions (Nair and van Staden 2014); and ifufunyane, a culture-bound syndrome (Niehaus et al 2005); and that it is applied as a healing agent on circumcision wounds (Dold and Cocks 2012). The plant has psychotropic properties which healers sometimes utilise for communicating with the ancestors (Mitchell and Hudson 2004) or, like Dam Toma, for trance healing. At the time when I was talking to /Kunta Kashe, I was unaware of this background and felt disconcerted. He explained:

If you take the malgif [ $\left.\mid a^{\prime} a n a\right]^{6}$ for himself, ${ }^{7}$ in a respectful relationship [/xoa kòaqà khòe $]$, not being afraid of each other: then he can help you. The bulb is poisonous. If you use it correctly, his nature/ being [tcá to'à hè kú $\mid x o a]$, he is owner of power [kgwexau], he becomes medicine [n/om] or to help you to heal other people. The plant, plants are living beings with the knowledge/knowing [!'hàn ka] of nature $[t c i ! u]$, the land [kxàlhò]. You must take/approach the plant for himself, from $\mathrm{kgwe}$ [power] and the knowledge/knowing of nature. Through that bulb, if you can warm its medicine/healing power [tzi $n / o m]$, you use it for the [trance] dance, then you see what the problem is and also the spirits [//gauwasi], but only if all are together/in relation [||káé].

While /Kunta Kashe's uncle Dam Toma had healing knowledge about using the plant, it has its own kgwe, its own ability to act, thus a kind of agentivity (see Rival 2012). The ability to trance and heal comes from the n/umkxao's openness to and management of the relationship with the kgwe (power), the breath/essence/good spirit [ma'a cua] of the plant itself, the environment, the air [ $n \mid a$ 'àn], the wind [màq], the spirits [//gauwasi], the sound of the singing and rhythmic clapping around the fire, the healers' sweat, the aroma and force of the veld, and the taste and smell of the plant infusion or decoction. The confluence and movement of all of the above elements link them across space and time in order to interpenetrate and transform each other (Low 2007, 572), thereby bringing about healing.

The plant not only has beneficial properties, but also the force/power imparted by nature to living things (Dold and Cocks 2012, 73). The discussions with /Kunta Kashe and my own experiences with medicinal plants led me to re-examine the literature on discussions of how to examine medicinal plants ontologically. Viveiros de Castro's (2004) work on Amerindian perspectivism presents ontology not as a multiplicity of views, but rather a singular view of different (multiple) natures (Škrabáková 2014, 169). Amerindian myths postulate that numerous cosmic entities (animals, humans, plants and spirits) share commonality and communicate with each other. Shamanism and hunting, for instance, intimate that animals, objects, plants and spirits can divulge an inner human form, commonly associated with their "soul" or "double." Humanity is viewed as a reflexive condition of the subject to itself, while animality (or vegetality) is the body's condition, observed from an external viewpoint. This ontological shift contrasts multi-culturalism with multi-naturalism and pluralist universal relationism (Viveiros de Castro 2004).

Descola $(2013,31)$ highlights the Amerindian propensity to approach particular "elements in the environment as persons," that is they are gifted with "cognitive, moral and social qualities analogous to those of humans." These approaches assimilate plants and spirits in the category of persons. Škrabáková $(2014,165)$ argues that plants play a key role in human existence, but are also viewed as "entities that act as humans and thus as social agents — not just in ... healing and magic, but also in everyday life."

While not all plants have the same enabling power or force, medicinal and magical plants have potency and are viewed as "masters," "teachers" or "doctors," able to impart strength and wisdom and to aid shamans in learning. Healers can mediate interaction between humans and plants (Škrabáková 2014, 172, 178). When harvesting a medicinal plant or plant-part for healing or magical purposes, one must do so alone and "apologize to the plant spirit and ask him to help in a situation where he wants to apply (it)" (177). Škrabáková thus argues for an ethnography that incorporates the viewpoint of the plant. 
While it is helpful to understand these perceptions of plants, Amerindian metaphysics cannot simply be transported to settings such as Namibia and Ju/'hoan speakers. However, they do offer useful ideas when reconsidering agencies/agentivity and/or the being of medicinal plants (Hall 2011; Sobiecki 2012, 2014).

In Namibia in 2017, /Ui Bo, also a healer, elaborated on the healing power of medicinal plants:

They [healing plants] know [łang] how to change/repair what is wrong [the sickness]. Medicinal plants have a good/strong spirit, they are of nature [tci kxao ]. I ask the plant for its strength/power to heal, but I must always give something back to the plant.

Certain medicinal plants have the power to bring about change and healing. This ability and knowledge comes from nature, the spirit, soul or breath-essence of the plant, apart from the skill of the healer and his respectful relationship with the plant. For /Kunta Kashe and /Ui Bo, medicinal plants can be understood as actants (see Latour 2005, 2014): they have agency, which is the effect of relations. To elaborate, I return to the literature in the next section.

\section{Rethinking medicinal plants as agents/actants}

Material semiotics focuses on the multiplicity of mutually constitutive and positioning actants, thereby raising the "non-human-ness" of agency (Jones and Cloke 2002, 79). Although not focused on medicinal plants, Jones and Cloke (2002) suggest a reconsideration of the material agency of trees. Hitchings $(2003,99)$ argues that gardened plants display energy and determination towards connection.

Here I turn to the agentic relationality of the aforementioned $C$. edulis. To do so, I draw on the work of Tsing $(2013,28)$. She attends to the more-than-human sociality of plants, "constituted in relations," and argues that plants have their own biography, a history of social relations that shape them over time. According to Mina Bruyns, a botanist with whom we worked, C. edulis is a pioneer species: it grows easily in disturbed soil and was transplanted from South Africa to the Mediterranean to cover verges along roads and railway tracks. C. edulis subsequently spread and became invasive there. It developed a relationship, called invasive mutualism, with the black rat (Rattus rattus), which eats its fruits and excretes seeds in droppings, thus simultaneously nourishing and propagating the plant.

In Matzikama, I dug indigenous $C$. edulis from soil beside a dirt road. I observed a dwarf succulent shrub, growing mat-like along the ground. The spreading C. edulis had put out clumps of roots from various nodes. According to Mina Bruyns, the plant's thick, fleshy leaves are adapted to low winter rainfall, dehydrating berg winds and summer heat. They have internal cells containing a gel substance that stores water and nutrients, which are used to hydrate photosynthetic cells when the plant is dessicated. Mina Bruyns explained:

C. edulis, part of the Karoo biome, are special plants that sometimes have to deal with less photosynthesis happening during the day, in a climate highly variable in moisture and nutrients. $C$. edulis' longevity, [its] triangular shaped leaves, [the] capacity of its fruit to completely dry without damaging the seed, the seeds' ability to stay dormant, [they all] increase its ability to overcome cyclical drought and heat. Our plants are awesome.

I contend that $C$. edulis, for all its rootedness, has a biography (Tsing 2013) and displays what Sander-Regier $(2009,63)$ calls "botanical agency." This, Sander-Regier argues, should be explored in a "more basic, bare-roots sense as something achievable by non-human actors." To illustrate, he focuses on gardeners who experience the "presence, intent, association and capacity" of plants (64), thus detaching agency from its close linkage to humans: as did Mina Bruyns when she emphasised C. edulis" "awesome" adaptations to survive.

C. edulis also evokes Tsing's (2013) emphasis on more-than-human sociality, as illustrated by its mutualism with rats in the Mediterranean. This sociality emerged differently in Matzikama. Bees and beetles, its pollinators, were visibly active on $C$. edulis' purple flowers. When I pulled 
at the plant, a concealed lizard flashed away. Field mice and a porcupine had nibbled at some of the ripe, aromatic fruits, attracting ants. Mina pointed out that the fleshy fruit did not split open to release its seedpods; the seeds were rather surrounded by a sweet, sticky, jelly-like mucilage, tasty to animals (and humans), and were dispersed in the animal's excreta. She narrated that certain animals, such as puff adders, hide among $C$. edulis to surprise their prey, ambushing small rodents feeding on the fruit or capturing lizards which, in turn, predate on insects attracted by the leftovers. According to Tsing (2013), the plant is thus entangled in more-than-human assemblages. C. edulis can propagate itself and exists in an entanglement not only with humans who use it as medicine (and food) or transport it to green or stabilise soil in another part of the world, but also with whole biomes, habitats, insects, animals and their "becomings" (Kirksey 2015, 773).

This relationality of medicinal plants was emphasised by Ju/'hoan healers in Namibia. The plants, they said, produce an effect in the soil, in the growth of other plants, in the environment and in animals. Medicinal plants induce a response in humans through their inherent potency, their own knowledge/knowledgeability, and their smell (tsà'á) or essence moving through the air, the wind and in breath. /Xhase /Ui, also a healer, said when he walks in the bush he is always

very alert/aware [!'hán], looking, breathing, smelling, listening, feeling the movement of ... birds, animals, heat, dust, grass, branches, of the breeze and the air ... I live in nature and I am of nature [Me ku keya tci te o tci kxao]. I am always aware, I look and listen everywhere, up, down, sideways, under bushes, over grass, through branches. I smell something, get a scent [tsà'á] ... I shiver/tremble [thárá] ... I understand it [the plant] called me ... I follow the thread [tsò].

According to Low $(2007,75)$,

wind or smells and pheromones draw and repulse organisms to their mutual ends. When the wind of an animal or plant enters a Khoisan body there is a unity between the two phenomena. Wind smells lock participants into a web of relationships. The essence of one organism connects with another.

The intermingling of essence, breath, wind and air signals to /Xhase /Ui, makes him tremble (as in trance) and is vital for healing. But many medicinal plants are administered internally and have "mutually inclusive physical, psychological and spiritual therapeutic effects" (Sobiecki $2014,2)$. These are activated through the interaction between ritual dynamics, the phytochemical synergy of the plants' therapeutic capacity, the mixtures utilised and the psyche of the user (Sobiecki 2012). N/umkxao like/Ui Bo emphasised the potentiality of medicinal plants to bring about transformation. /Kunta Khase explained that the plant he had used affected him and the sick person. Asked to clarify, he said the plant "made/turned it [sickness/sick person] into something else [kuru ka ko tci dore]": by bringing about transformation, it could heal [dù !kóbó].

Narby (2006) conceptualises the adaptability and flexibility of healing plants as "knowingness" when he interrogates scientific research and Western human-centred meanings attached to knowledge. He translates this from the Japanese chi-sei, the "capacity to know" (99), and redefines this capacity as something not restricted to humans: concluding that "knowingness" can be attributed to plants. I contend that this is also what the n/umkxaosi were intimating. Arguably, the "action" of medicinal plants not only comes from the healer: they can be said to "act" in their "own right" (Narby 2006, 99).

The idea that medicinal plants have certain potency emanating from nature was emphasised in our Matzikama research. While there were several bush doctors and herbalists practising, some old people consulted neither healers nor health care providers but relied on medicines from the veld (Pasquallie 2016; Nathen 2016). Aunt Eva Grootboom, a lively 73-year-old who runs each afternoon along the dry hills of Kliprand, had no time for bossiesdokters [herbalists] or Rastafari herbalists. She was known for her medicinal plant knowledge, prepared her own mixtures and drank them daily as prophylaxis. She regularly climbed over fences of surrounding farms to walk in nature [in die natuur]. Plants, she argued, had the knowledge/knowingness of nature and the veld [kennis van die natuur en die veld]. The way she talked about medicinal plants emphasised their 
vitality [lewenskrag] and liveliness/aliveness [lewendigheid]. Like other people in the Matzikama area (Nathen 2016; Pasquallie 2016), Aunt Eva postulated that a plant could unexpectedly entangle humans in relationality. She described, for example, how she was searching in the veld for a specific plant to treat a festering abscess in her nephew's neck when she stumbled over a bulb $[\mathrm{bol}]^{8}$ that had apparently been unearthed by rain the day before. That bulb "was telling/signalling to me, 'See, use me!'” [hy't my gesein, 'Sien, gebruik my!'] she explained. She applied the scales of the plant to the abscess until it had healed.

In another instance, we were searching for Lessertia frutescens (L.) Goldblatt \& J.C. Manning in the Gifberg mountains in Matzikama. A Rastafari herbalist ventured into thick brush and eventually returned with it. He said he only found it because the branches of another medicinal plant had entangled his arm, forcing him to bend over, which was when he saw the kankerbos. He explained that the spirit [gees] of the plant "pulls you back" [trek jou terug] (see Nathen 2016). From their own biodiverse entanglement, the plants had also enmeshed him. Many study participants conceptualised medicinal plants as "agentic beings, rather than as mute materials or mere messages" (Ryan 2012, 102). The plants' materiality or aroma not only arrested the attention of the participants: they were understood as relational, lively and potent in and of themselves.

To explore this idea I return to the literature. Multi-species "ethnography" offers an approach to reconsider plants. ${ }^{9}$ By untangling "a multitude (whether of men or of beasts) associated or living together" (Kirksey 2015, 759), multi-species motivates for attention to life within a shifting aggregation of "agentive beings." In the case of medicinal plants, these would involve them as biophysical entities that animate life (Ogden, Hall, and Tanita 2013, 6), that is, their vital materialities (see Nathen 2016). Ingold (2013), however, is critical of the concept "species" and argues for anthropology beyond multispecies and beyond humans. He only briefly mentions plants, but proposes that we could learn with and from their "becomings" through participating in their lives (21).

But how to explore this? Although not specifically focusing on medicinal plants, there is a growing body of research in anthropology (Beyer 2010; Hartigan 2013), philosophy (Marder 2013), environmental studies (Ryan 2011, 2012), human-plant geography (Head and Atchison 2009; Hitchings and Jones 2004) and human-plant studies (Ryan 2012) that is re-evaluating the transformational power of plants, their sensorial and communicative activities (Chamovitz 2013; Maher 2017), as well as their more-than-human sociality and temporality (Gan 2016).

Connectivity between plants, animals, humans, soil, insects, birds, traditional healers, herbalists, producers and others is emphasised by the botanist Trewavas (2003). He reaffirms the ability of plants to perceive or sense the environment and fine-tune their structure and morphology, physiology and even phenotype to the given conditions. Extending insights from botany (Hall 2011; Trewavas 2014), a number of scholars describe the social-cultural power of plants and plant intelligence, as well as their volitionality, vibrancy and communication (Beyer 2010; Doyle 2012; Ogden, Hall, and Tanita 2013, 16; Ryan 2012).

In botany, Hall $(2011,156)$ promotes the philosophical turn that plants should be accorded a form of "personhood." Another seminal publication that decentres humans and suggests analysis in terms of entanglements is Kohn's How Forests Think (2013). Probing the multifaceted, hybrid tropical world of the Amazon, he attends to "the semiosis of life" (55), combining this with insights into bio-ecological processes of the forest. Signs are generated and interpreted by a forest, in a vital and living wood-wide web. Kohn develops academic tools to think "beyond the human" and perceive non-humans as active. Tropical forests are populated by varieties and numbers of "living selves" (6), including closely associated species that interact and co-evolve in complex ways as part of "proliferating webs of habits" (62). Forests, Kohn argues, magnify and make scholars alert to "the ways life thinks" (78). The forest and its myriad life forms make sense of the world and represent it without language. All livings beings, from epiphytic cacti to rubber trees, can be regarded as selves. In critique of Latour, Viveiros de Castro and Descola, Kohn 
argues that we are "colonized by certain ways of thinking about relationality" (21) because we often do not discern the logic and dynamics of biological processes, living movement and action. Thus we need broader, more inclusive and dynamic insights into the entire process to grasp the semiotic qualities of life and make "the ways life thinks" apparent $(78,182)$. In Kohn's analysis, plants not only have the potential to have representational abilities, but also purpose, interactions and communications. Although Kohn does not attend to plants per se, his work offers a register to consider connections, assemblages and relations by rethinking these as associations between multiple selves. It is unclear, however, to what extent such an analysis can guide enquiry into medicinal plants in other bioecologies, such as arid Namibia or the Matzikama area, or into tracing when plants migrate, enter scientific research settings or are sold in herbal markets.

When medicinal plants are harvested, traded and consumed, they arguably become part of the permeable social relations between humans and non-humans, which complicates the supposed distinctions between them (Whatmore 2002). Whatmore argues that social theorists, like those who draw on Deleuzian rhizomatic thinking, are often not mindful of the material force or lively potency of rhizomes as plants - that is, what they "do" and/or what spaces they inhabit (6-7). By comparison, Houle $(2011,95,100)$ searches for "another route for plant-thought," drawing on Deleuze and Guattari's rhizomatic thinking, to ponder what a philosophical botany will resemble if "becoming-plant" was imagined. She seizes on studies on plant communication, indicating the individuality of plants and their co-evolution with and in a variety of environmental relations, which are in turn evolving in multifaceted ways. She describes how plant signalling happens between, not only within, different species and points towards the political and ethical implications of expounding the notion "becoming-plant," in an effort to change our penchant for "human thinking and human action" (112).

Marder $(2013,2)$, in turn, deconstructs the "ethical neglect," exclusion and abjection of vegetal life in the history of Western philosophy. Sketching perceptible attributes of plant behaviour found in the work of a range of philosophers, he shows that such vegetal behaviour corresponds with many aspects of human life. By ignoring vegetal beings, we neglect possibilities for fertile insights into our existence. Marder wants to scrutinise the world of plants "from the standpoint of the plant itself," a vegetal ontology (9). And yet, although he argues for the insertion of plant life into Western ethical/philosophical discourse, his work nonetheless remains abstract and ignores empirical application.

In contrast, Myers' (2015) dense fieldwork explores how plant scientists relate ideas about plant sensing, what this means to and for them in their work, and how they can report on their findings in academic publications. She reviews recent publications of what she calls the "plantturn," literature that attends to plant agency, and stresses that such texts inspire us to consider an expansion of conceptions of "intelligence, thought, communication, and cognition to plants, those organisms that have always appeared so passive, so mute, so still" (40). Through painstaking experiments, plant scientists become attentive and able to comprehend the complex world of plant sensing, engaging in what Myers refers to as "plantification" or "vegetalization" $(19,20)$ : to penetrate plant-sensing, gaining ingress through kinds of embodied transmutation and, in turn, offering us new concepts and possible methodological tools for future studies.

\section{Rethinking medicinal plants in disciplinary intersections}

Finally, some researchers argue that research processes obscure, reconfigure and erase the roles, knowledge and rituals of traditional healers and healing systems regarding medicinal plants. When medicinal plants become mobile and are studied in laboratories, as with $S$. tortuosom, they are conceivably dislocated from the knowledge and rituals of the healers (Langwick 2011). Hence, medicinal knowledge is seen as not necessarily located within entities such as plants, but rather in the therapeutic transformation/s that emerge from healing "encounters and their traces" (Geissler and Prince 2009, 1). Yet our research in Matzikama indicates that knowledge about medicinal 
plants is dispersed ${ }^{10}$ and that such plants can also affect the healer and/or the sick through their therapeutic potentialities.

While people often consume medicinal plants, the most discernible effects are seen with socalled "dream" plants, as, for example, Silene undulata and Silene capensis (ubulawu) ${ }^{11}$ (Dold and Cocks 2012). It is regarded as sacred by diviners [amagrirha in isiXhosa] who value the prepared plants for their ability to induce prophetic and healing dreams. Usually plant roots are pounded and a little water (and sometimes mixtures of other ubalawo) is added. It is whipped into a foam and then rubbed on the body to cleanse it, ingested in healing practices or used to "learn healing knowledge" (Sobiecki 2012, 218). In a personal comment, Denver Davids, ${ }^{12}$ who used ubalawo under the supervision of an igrirha [diviner], reported lucid, colourful dreams. When I used the plants, I experienced vivid, kaleidoscopic dreams of fantastical landscapes, while simultaneously being aware that I was dreaming. As Sobiecki $(2012,219)$ argues, all ubulawo preparations "have psychoactive affects as a common basis of action."

To interrogate these plants and their capacities, I turn to Verran $(2010,3)$ who discusses research on Clerodendrum myricoides, a toxic medicinal plant in Kenya, to unpack the "extracting" activities of participating chemists and healers as a kind of "negotiation with an active nature." She argues that plant decoctions and their compounds are "active agents, quite different in where they are to be found and what they are used for." They "should also be recognised, each in its own right ... as having agency."

How can anthropologists think about these issues anew? In South Africa, Laplante (2014, 2015) studied the interstices between traditional and scientific ways of preparing plant medicines in preclinical studies on Artemisia afra Jacq. Ex Willd. (umhlonyane) as a phyto-therapeutic medicine in experimental tuberculosis treatment. She moves between phenomenology and actor-network theory to "engage conversation between different ways of making medicine 'work' in-the-world" $(2015,47)$, stressing that traditional healers, Rastafari herbalists, "biochemists, pharmacologists, (and) immunologists" $(2014,19)$ all share concerns with "knowing life in the hope of healing" $(2015,10)$. In this process, certain ontologies are brought into being, while others became less valid or vanish $(2014,1)$. She contends that plants "disappear" in molecular biology and are replaced by "new entities," namely "molecular configurations in a plant used in practice" $(2015,207)$.

As anthropologists, we can thus analyse the ways in which people understand and represent plants' chemical signals (Attala 2014), as, for example, for the blackcurrant-mint fragrance of Agasthosma betulina (buchu), smelled during fieldwork in the Matzikama area. Aunt Eva opined that the natuurkennis [knowledge of nature] and power of buchu is signalled through this aroma. The healing power inhered in the intermingling of odour/essence. The air/wind was similarly emphasised by the n/umkxaosi in Namibia. Low $(2007,333)$ refers to the smell of buchu as "an agent of physical and mental transformation." I also felt soothed by the fragrance of buchu and used it to clear a urinary tract infection. I chewed fermented and unfermented dried $S$. tortuosum during fieldwork. The first time, I promptly fell asleep. Afterwards I chewed less and quickly experienced a feeling of relaxation. Ingesting plants is a way to mobilise human-plant relationality: according to Attala $(2014,1)$, it can also be understood as "co-mingling or molecular entanglements" at a corporeal level. While I learned from the literature and pharmacists about the active compounds in these plants and the synergetic effects between them, the plants affected me experientially and sensorially.

In forging a new way of engaging with plants, Green and her colleagues $(2015,10,12)$ aim to untangle the complexity of interdisciplinary research focused on medical plants as they try to unpack "how we know" while also trying to "respect medicinal plants as differentially knowable." Cohen (2015) scrutinises problematics about the actualities "being done" when bossiedokters and molecular biologists work in different ways with medicinal plants in Namaqualand. He draws on Latour's theory of assemblages of diverse entities, as well as of translations and "“crossings' between modes of existence" that occur when there is a convergence of humans and actants such as 
plants, solvents, tests and representations (92). Cohen (179) offers possibilities for future empirical and theoretical work and emphasises the complexity of plants:

They are alive, shifting, sensitive, moving and changing, exhibiting their own kinds of agency; they are chemically dynamic and complex, and also offer to the human senses a rich range of experience in their appearance, smells, and tastes. And it is perhaps partly because of this complexity that they can be enrolled in different kinds of ecologies, and act as a crossing point for many different kinds of relations and the modes of existence passing through them.

As shown in the literature, plant substances and their related ways of knowing travel, create new confluences and elicit new relationships. Where apparently dissimilar knowledge-driven perspectives interface around medicinal plants, the different knowledge-bases originate from a range of viewpoints and practices. While these perspectives diverge from one another, they also connect or converge, as, for example, in the bodies of medicinal plant users. They become intertwined here in complex settings where plants-as-medicines have an effect.

In order to make sense of knowledge interfaces, Gibson and Kilian (2013) interrogated the making of South African clinical trials of encapsulated L. frutescens. Their focus was on how the plant-as-medicine materialised in a range of efforts to mediate an emerging, fragile composite knowledge through texts, discussions, performances, rituals and other formats concerning the plant medicine. The authors stress that the "hybrid knowledge" that arises "involves not only the plant but also structures simultaneously generated and enacted into reality" $(2013,181)$, bringing these into assemblages. Ultimately, I contend that it may be useful for us as anthropologists to regard medicinal plants as agentic, as well as sympoietic or continuously "making-with" others in assemblages (see Haraway 2016).

\section{Conclusion}

Medicinal plants may be differently studied and represented in the literature, but several disciplines share a concern with them. Plants such as $S$. tortuosum have assumed worldwide biocultural significance in political, economic, intellectual and knowledge settings. Harvested, traded and investigated, medicinal plants are a crucible for what we term social relations between humans and non-humans, blurring supposed distinctions between them. Plants like C. edulis are agentive. $C$. edulis affects and adapts to the environment, naturally materialising in specific biomes; it grows, flowers, bears fruit and propagates itself through seeds and cycles of drought and rain. In so doing, plants become (see Tsing 2013) within their ecological and more-thanhuman assemblages. Plants are sympoietic: a Rastafari was compelled to look for L. frutescens on Gifberg, where it naturally emerges. He found it intertwined in biodiverse assemblages and was, in turn, entangled by the assemblage.

Medicinal plants are acted on: removed, pressed, catalogued, chopped up, transplanted and exploited. In their biocultural diversity, plants like $S$. tortuosum and A. betulina act on and within people: relieving anxiety and having an antibacterial and anti-inflammatory effect in human bodies. Enmeshed with humans, these plants, arguably, encourage their own cultivation.

In much anthropological literature, it is argued that the ability of medicinal plants is activated by the knowledge of healers, their rituals, preparation methods and interaction with the spirits. This article also indicates healers' and users' conceptualisation of such plants as living beings with agentative possibilities, even as active agents in co-producing knowledge. In Namibia, n/umkxaosi underscored the potentiality of medicinal plants to bring about transformation through their own potentiality, derived from and in response to their more-than-human assemblages and, thereby, potentiating healing. The chemical potentiality of psychoactive plants like Cannabis, Boophone and Silene arguably become enmeshed with healers' and users' collective and individual histories, their physiological and psychosocial dispositions, as well as their beliefs, meanings and intentions to relationally become-with (Tsing 2013) in healing and bringing about spiritual, mental and therapeutic effects. 
N/umkxaosi and Rastafari who participated in the study raised the issue of respectfulness and concern for medicinal plants. Calls to extend ethical consideration to plants will demand new methodological research approaches (Ingold 2013). Consequentially, Myers $(2017,3)$ argues that we need to develop "an aspirational episteme and way of doing life in which people come to recognise their profound inter-implication with plants."

Like a number of recent publications, this paper raises questions about the capacity of plants to know, communicate and affect, albeit differently. The agentivity of plants and their particular "knowingness" or abilities have not yet been extensively explored in relation to knowledge production in anthropology. This may in part be because we lack the necessary methodological tools, language and terminology to do so. It may also mean that we have to learn to regard plants differently.

\section{Acknowledgements}

The fieldwork for this paper was supported by the National Research Foundation [grant number 87804]. My gratitude goes to the participating n/umkxaosi, the people of Matzikama and the reviewers.

\section{Notes}

1. "Traditional" is a contested term. The World Health Organisation has a specific, albeit problematic definition. I use "traditional" here to refer to ideas, understandings, realities, experiences, practices and such that have historically been utilised for health promotion and treatment and are perceived by local people as part of "traditional healing."

2. There is an active online site where the use of Sceletium is discussed (Seattle Stranger 2012).

3. Online discussions indicate that $S$. tortuosum is grown by enthusiasts in, for example, New Zealand.

4. The habit of a plant refers to the format it adopts (bush, tree, vine, etc.).

5. As per agreement with study participants, pseudonyms are used throughout.

6. The Ju/'hoansi who participated in this study understand Afrikaans well. They nonetheless preferred to speak their own language. I spoke Afrikaans and a certified guide and native Ju/'hoan speaker translated. Because the healers understood me as well as the translation, they interrupted the translator when they did not agree with his translation. I also often asked for more clarity on words and meanings. We would then all engage in a discussion about the most appropriate translation from the Ju/'hoan language into Afrikaans or vice versa. There are a number of words which cannot be directly translated into Afrikaans or English. In such cases I use more than one word to try to provide an approximation of the meaning. I also asked the translator to write words down for me and subsequently checked these against a Ju/'hoan English Dictionary as I translated the interviews from Afrikaans to English for the purpose of this article. The healers did not consent to making the translations or their transcripts available to others.

7. The use of masculine gender relates to the Afrikaans translation, but could be understood as gender neutral in this particular case. The use of "him" indicates that medicinal plants are seen as animate, rather than as male per se. There are at least five genders in the Ju/'hoan language.

8. Using Aunt Eva's description of the bulb, a botanist opined that it probably was $B$. disticha.

9. See Ogden, Hall, and Tanita (2013) for a review of multi-species ethnography.

10 Not all healers are knowledgeable about or use all medicinal plants. Many "lay" people, especially the elderly, have extensive medicinal plant knowledge and also utilise them frequently.

11. Ubulawu means the "spirit that controls one" in isiXhosa.

12. Denver Davids, a doctoral student who was a researcher in the project, preferred the use of this own name rather than a pseudonym.

\section{ORCID}

Diana Gibson (iD) https://orcid.org/0000-0002-6846-603X

\section{References}

Attala, L. 2014. "Conversations Over Dinner: A Phyto-centric Exploration of Being Edible." Botanical Ontologies: A Cross-Disciplinary Forum on Human-Plant Relationships, Oxford, May 16-17. https:// www.academia.edu/7091917/Conversations_over_dinner_a_phyto-centric_exploration_of_being_edible

Beyer, S. 2010. Singing to the Plants: A Guide to Mestizo Shamanism in the Upper Amazon. Albuquerque: University of New Mexico Press. 
Bussmann, R.W. 2013. "The Globalization of Traditional Medicine in Northern Peru: From Shamanism to Molecules." Evidence-Based Complementary and Alternative Medicine Article ID 291903: 1-46. http:// dx.doi.org/10.1155/2013/291903

Chamovitz, D. 2013. What a Plant Knows: A Field Guide to the Senses. New York: Scientific American Books.

Cleversley, K. 2002. "Sceletium tortuosum - Kanna." Entheology.com. http://entheology.com/plants/ sceletium-tortuosum-kanna

Cohen, J.B. 2015. "Kruiedokters, Plants and Molecules: Relations of Power, Wind, and Matter in Namaqualand." PhD diss., University of Cape Town.

de Roode, J.C., T. Lefèvre, and M.D. Hunter. 2013. "Ecology: Self-medication in Animals." Science 340 (6129): 150-151.

Descola, P. 2013. Beyond Nature and Culture. Translated by Janet Lloyd. Chicago: University of Chicago Press.

Dold, T., and M. Cocks. 2012. Voices in the Forest: Celebrating Nature and Culture in Xhosaland. Auckland Park: Jacana Press.

Doyle, R. 2012. "Healing with Plant Intelligence: A Report from Ayahuasca." Anthropology of Consciousness 23 (1): $28-43$.

Gänger, S. 2015. "World Trade in Medicinal Plants from Spanish America, 1717-1815.” Medical History 59 (1): 44-62.

Gan, E. 2016. "Time Machines: Making and Unmaking Rice." PhD diss., University of California.

Geissler, P.W., and R.J. Prince. 2009. "Active Compounds and Atoms of Society: Plants, Bodies, Minds and Cultures in the Work of Kenyan Ethnobotanical Knowledge." Social Studies of Science 39 (4): 599-634.

Gibson, D., and S. Kilian. 2013. "The Making of Sutherlandia as Medicine." In Contested Ecologies: Dialogues in the South on Nature and Knowledge, edited by L. Green, 162-186. Cape Town: HSRC Press.

Green L., D.W. Gammon, M.T. Hoffman, J. Cohen, A. Hilgart, R.G. Morrell, H. Verran, and N. Wheat. 2015. "Plants, People and Health: Three Disciplines at Work in Namaqualand." South African Journal of Science 111 (9\&10), Article ID \#2014-0276, 12 pages. http://dx.doi.org/10.17159/sajs.2015/20140276

Hall, M. 2011. Plants as Persons: A Philosophical Botany. Albany: SUNY Press.

Haraway, D. 2016. Staying with the Trouble: Making Kin in the Chthulucene. Durham: Duke University Press.

Hartigan, J. 2013. "Mexican Genomics and the Root of Racial Thinking." Cultural Anthropology 28 (3): 372-395.

Hayden, C. 2002. When Nature goes Public: The Making and Unmaking of Bioprospecting in Mexico. Princeton: Princeton University Press.

Head, L., and J. Atchison. 2009. "Cultural Ecology: Emerging Human-Plant Geographies." Progress in Human Geography 33 (2): 236-245.

Hitchings, R. 2003. "People, Plants and Performance: On Actor Network Theory and the Material Pleasures of the Private Garden." Social and Cultural Geography 4 (1): 99-113.

Hitchings, R., and V. Jones. 2004. "Living with Plants and the Exploration of Botanical Encounter within Human Geographic Research Practice." Ethics, Place and Environment 7 (1\&2): 3-18.

Hokkanen, M. 2012. "Imperial Networks, Colonial Bioprospecting and Burroughs Wellcome \& Co.: The Case of Strophanthus kombe from Malawi (1859-1915)." Social History of Medicine 25 (3): 589-607.

Houle, K.L.F. 2011. "Animal, Vegetable, Mineral: Ethics as Extension or Becoming? The Case of BecomingPlant." Journal for Critical Animal Studies 9 (1\&2): 89-116.

Ingold, T. 2013. "Anthropology Beyond Humanity." Suomen Anthropologi: Journal of the Finnish Anthropological Society 38 (3): 5-23.

Jones, O., and P. Cloke. 2002. Tree Culture: The Place of Trees and Trees in Their Place. Oxford: Berg Publishers.

Kirksey, E. 2015. “Species: A Praxiographic Study.” Journal of the Royal Anthropological Institute 21 (4): $758-780$.

Kohn, E. 2013. How Forests Think: Toward an Anthropology Beyond the Human. Berkeley: University of California Press.

Langwick, S.A. 2011. Bodies, Politics, and African Healing: The Matter of Maladies in Tanzania. Bloomington: Indiana University Press.

Laplante, J. 2014. "On Knowing and Not Knowing 'Life' in Molecular Biology and Xhosa Healing: Ontologies in the Preclinical Trial of a South African Indigenous Medicine (Muthi)." Anthropology of Consciousness 25 (1): 1-31.

Laplante, J. 2015. Healing Roots: Anthropology in Life and Medicine. Oxford: Berghahn Books. 
Latour, B. 2005. Reassembling the Social: An Introduction to Actor-Network-Theory. Oxford: Oxford University Press.

Latour, B. 2014. "Agency at the Time of the Anthropocene." New Literary History 45 (1): 1-18.

Low, C.H. 2007. "Different Histories of Buchu: Euro-American Appropriation of San and Khoekhoe Knowledge of Buchu Plants." Environment and History 13 (3): 333-361.

Maffi, L. 2007. "Biocultural Diversity and Sustainability." In The SAGE Handbook of Environment and Society, edited by J. Pretty, A. Ball, T. Benton, J. Guivant, D.R. Lee, D. Orr, M.J. Pfeffer, and H. Ward, 267-277. London: Sage.

Maher, C. 2017. Plant Minds: A Philosophical Defense. New York: Routledge.

Marder, M. 2013. Plant-Thinking: A Philosophy of Vegetal Life. New York: Columbia University Press.

Mitchell, P., and A. Hudson. 2004. "Psychoactive Plants and Southern African Hunter-Gatherers: A Review of the Evidence." Southern African Humanities 16 (1): 39-57.

Myers, N. 2015. "Conversations on Plants Sensing: Notes from the Field." NatureCulture, no. 03: 35-66. https://www.academia.edu/16543355/Conversations_on_Plant_Sensing_Notes_from_the_field

Myers, N. 2017. "From the Anthropocene to the Planthroposcene: Designing Gardens for Plant/People Involution." History and Anthropology 28 (3): 297-301.

Nair, J.J., and J. van Staden. 2014. "Traditional Usage, Phytochemistry and Pharmacology of the South African Medicinal Plant Boophone disticha (L.f.) Herb. (Amaryllidaceae)." Journal of Ethnopharmacology 151 (1): $12-26$.

Narby, J. 2006. Intelligence in Nature: An Inquiry into Knowledge. New York: Tarcher/Penguin.

Nathen, T. 2016. "Exploring 'Assemblages:' A Multispecies Ethnography of the Relationship between Plants and People in the Gardens and Mountains of Klawer in the Matzikama Municipal Region, South Africa." MA thesis, University of the Western Cape.

Niehaus, D.J., D.J. Stein, L. Koen, C. Lochner, J.E. Muller, N.I. Mbanga, R.A. Emsley, and J.M. Gorman. 2005. "A Case of 'Ifufunyane': A Xhosa Culture-bound Syndrome." Journal of Psychiatric Practice 11 (6): 411-413.

Ogden, L.A., B. Hall, and K. Tanita. 2013. "Animals, Plants, People, and Things: A Review of Multispecies Ethnography." Environment and Society 4 (1): 5-24.

Osseo-Asare, A.D.A. 2014. Bitter Roots: The Search for Healing Plants in Africa. Chicago: University of Chicago Press.

Pasquallie, M. 2016. "Die stam van die gemeenskap: An Exploration of Hypertension and Herbal Treatment amongst the Elderly in Nuwerus." MA thesis, University of the Western Cape.

Petrovska, B.B. 2012. "Historical Review of Medicinal Plants' Usage.” Pharmacon Review 6 (11): 1-5.

Philander, L.E. 2010. "An Emergent Ethnomedicine: Rastafari Bush Doctors in the Western Cape, South Africa." PhD diss., University of Arizona.

Pieroni, A., and I. Vandebroek., eds. 2007. Traveling Cultures and Plants: The Ethnobiology and Ethnopharmacy of Human Migrations. New York: Berghahn Books.

Pollan, M. 2002. The Botany of Desire: A Plant's Eye-View of the World. New York: Random House.

Rival, L. 2012. "The Materiality of Life: Revisiting the Anthropology of Nature in Amazonia." Indiana, no. 29: 127-143. http://dx.doi.org/10.18441/ind.v29i0.127-143

Ryan, J.C. 2011. "Cultural Botany: Towards a Model of Transdisciplinary, Embodied, and Poetic Research into Plants." Nature and Culture 6 (2): 123-148.

Ryan, J.C. 2012. "Passive Flora? Reconsidering Nature's Agency through Human-Plant Studies (HPS)." Societies 2 (3): 101-121.

Sander-Regier, R. 2009. "Bare Roots: Exploring Botanical Agency in the Personal Garden.” Topia: Canadian Journal of Cultural Studies 21 (1): 63-84.

Schiebinger, L. 2004. Plants and Empire: Colonial Bioprospecting in the Atlantic World. Cambridge: Harvard University Press.

Seattle Stranger. 2012. "Kanna (Sceletium tortuosum) | Some Experience | Very Underrated Ethno!!” Bluelight. http://www.bluelight.org/vb/printthread.php?s=058f860f1440f2f5dfc183dd3acb8a4a\&t=613748 $\& \mathrm{pp}=25 \&$ page $=1$

Škrabáková, L. 2014. "Amerindian Perspectivism and the Life of Plants in Amazonia.” In Non-humans in Social Science: Ontologies, Theories and Case Studies, edited by K. Pauknerová, S. Marco, and P. Gibas, 165-185. Červený Kostelec: Pavel Mervart.

Smith, M.T., N.R. Crouch, N. Gericke, and M. Hirst. 1996. "Psychoactive Constituents of the Genus Sceletium N.E.Br. and other Mesembryanthemaceae: A Review." Journal of Ethnopharmacology 50 (3): 119-130.

Sobiecki, J.-F. 2012. "Psychoactive Ubulawu Spiritual Medicines and Healing Dynamics in the Initiation Process of Southern Bantu Diviners." Journal of Psychoactive Drugs 44 (3): 216-223. 
Sobiecki, J.-F. 2014. "The Intersection of Culture and Science in South African Traditional Medicine." Indo-Pacific Journal of Phenomenology 14 (1): 1-11. http://www.scielo.org.za/scielo. php?script $=$ sci_arttext\&pid=S1445-73772014000100006

Terburg, D., S. Syal, L.A. Rosenberger, S. Heany, N. Gericke, D.J. Stein, and J. van Honk. 2013. "Acute Effects of Sceletium tortuosum (Zembrin), a Dual 5-HT Reuptake and PDE4 Inhibitor, in the Human Amygdala and its Connection to the Hypothalamus." Neuropsychopharmacology 38 (13): 2708-2716.

Trewavas, A. 2003. "Aspects of Plant Intelligence." Annals of Botany 92 (1): 1-20.

Trewavas, A.J. 2014. Plant Behaviour and Intelligence. Oxford: Oxford University Press.

Tsing, A. 2013. "More-than-Human Sociality: A Call for Critical Description." In Anthropology and Nature, edited by K. Hastrup, 27-42. New York: Routledge.

van Andel, T., and P. Westers. 2010. "Why Surinamese Migrants in the Netherlands Continue to Use Medicinal Herbs from their Home Country." Journal of Ethnopharmacology 127 (3): 694-701.

Verran, H. 2010. "The Natural Products Chemist and the Traditional Healer: A Thought Experiment about Science's Engagement with the Public in Africa." Paper presented at The Public Understanding of Science in Africa workshop, September 22-24, Nairobi, by the British Institute of East Africa.

Viveiros de Castro, E.B. 2004. "Exchanging Perspectives: The Transformation of Objects into Subjects in Amerindian Ontologies." Common Knowledge 10 (3): 463-484.

Whatmore, S. 2002. Hybrid Geographies: Natures, Cultures, Spaces. London: Sage. 